\title{
Length of maternity leave and health of mother and child - a review
}

\author{
Katharina Staehelin, Paola Coda Bertea, Elisabeth Zemp Stutz \\ Institute of Social- and Preventive Medicine, University of Basel, Switzerland
}

Submitted: 21 October 2005; Revised: 10 October 2006; Accepted: 5 December 2006

\section{Summary}

Objectives: Assessment of the literature on the length of maternity leaves and health of mothers and children; evaluation of the Swiss situation in view of the maternity leave policy implemented in 2005.

Methods: Review of thirteen original studies identified by PubMed using topic-related terms.

Results: A positive association was shown between the length of maternity leave and mother's mental health and duration of breastfeeding. Extended maternity leaves were also associated with lower perinatal, neonatal and post-neonatal mortality rates as well as lower child mortality; however, results are obtained in ecological studies. There is less evidence regarding other health outcomes. The new policy in Switzerland extends maternity leave for a considerable number of women to 14 weeks. With this prolongation, fewer depressive symptoms and longer breastfeeding duration can be expected, while benefits regarding other health outcomes would warrant longer leaves.

Conclusions: Longer maternity leaves are likely to produce health benefits. The new policy in Switzerland will probably improve the situation of those women, who previously were granted only minimal leave and/or mothers with additional social risk factors.

Keywords: Maternity leave - Maternal health - Child health Breastfeeding - Review - Switzerland.

In the last decades, there has been a marked increase of women in the labour force of industrialised nations, mainly as a consequence of an increase of women with children remaining in paid work. Overall, the average employment rate of women in the European Union in 2002 was $47.6 \%$ (Bundesamt für Statistik 2004). In Switzerland it was even higher, at $59.4 \%$. The Swiss employment rate of 25- to 45-year-old mothers with children below the age of 6 years has considerably increased from $40 \%$ in 1990 to $62 \%$ in 2000, while the employment rate of women of comparable age without children has risen only slightly. Against this background, public policies regulating maternity and employment, such as paid maternity leave, gain importance.

In most industrialised countries, national policies for (paid and job-protected) maternity leave were established decades ago (Kamerman 2000). Since the 1990s, a minimum of 3 months parental leave has been mandatory within the European Union, and there is a binding guideline for at least 14 weeks of maternity leave (Kommission der Europäischen Gemeinschaften 1999; Kommission der Europäischen Gemeinschaften 2003). In most countries, however, the actual length exceeds this minimal standard by far (Bundesamt für Sozialversicherung 2004; MISSOC 2004). The new national legislation in Switzerland, which has been in effect since 1 July 2005, foresees paid maternity leave of 14 weeks, guaranteeing $80 \%$ of the previous wage for all employed women. Thus, this legal regulation, although a new achievement in Switzerland, remains limited when compared internationally (Bundesamt für Sozialversicherung 2004; MISSOC 2004).

Maternity leave is considered an element of maternity protection and benefits of policies are presumed to include women's and child health. Until the 1990s no direct empirical evidence existed to support this assumption. However, positive health effects were postulated based on the high prevalence of symptoms of mothers in the first postpartum year and the higher symptom incidence of children in day care compared to children cared for at home (McGovern et al. 1992). A comparison of maternal and infant mortality across the European Union and Switzerland shows no relationship with maternity leave 
regulations though: while Scandinavian countries belong to the nations with the most extended maternity provisions and also have among the lowest rates of maternal and infant mortality, maternal mortality rates in Switzerland are very low too, despite far less advanced maternity policies. On the other hand, there are countries with less favourable health indicators than Switzerland despite more extended regulations, such as the United Kingdom or Greece (Bundesamt für Sozialversicherung 2004; WHO 2004). However, in a case study on the impact on breastfeeding of labour market policy and practice in Ireland, Sweden and the USA, the policy package in Sweden with its extensive well-paid parental leave was interpreted as an important factor behind Sweden's enviable child health statistics (Galtry 2003).

This article reviews the literature on the association between the length of maternity leave and maternal and child health indicators and evaluates the results with regards to the current regulation pertaining to maternity leave in Switzerland.

\section{Methods}

\section{Search strategy}

The literature search targeted studies on the association between the length of maternity leave and health endpoints for mother and child. The term maternity leave was defined to include maternity leave, granting employed mothers a limited job-protected period around childbirth, as well as parental leave, which is a gender-neutral job-protected leave from employment and usually follows after the exhaustion of maternity leave (Kamerman 2000).

The searches were conducted in PubMed using topic-related search terms, either alone or in combination, both for the exposure (maternity leave, parental leave) and for the health outcomes (health, mother's/women's/maternal/infant/child health, maternal mortality, infant mortality, breastfeeding).

Studies were included for review that were conducted and published since 1990, carried out in Europe or the United States, and published in English, French or German. In a first step of the selection process, meta-analyses and reviews were searched for, in a second step, original articles. A few original articles were chosen from the reference lists of included papers. One study was excluded since it was a pilot study (Gjerdingen et al. 1991). Overall, 13 original studies were selected for review. For the evaluation of the situation regarding maternity regulations in Switzerland, the paper relies on the fact sheet on the revision of the Income Replacement Scheme ("Erwerbsersatzordnung"), published by the Federal Office of Social Security, that describes the new regulation of paid maternity leave in Switzerland (Bundesamt für Sozialversicherung 2004).

\section{Included studies}

Of the studies included in the review, five are longitudinal, six cross-sectional, and two ecological. Nine studies were conducted in the USA, one each in Italy and Turkey. The two ecological studies included European Countries, USA, Canada, Japan and New Zealand. Data collection goes back to the late 1980s and early 1990s, except for the ecological studies that go back to 1959 and 1969. The size of the study populations ranges from 141 to 1762 women. Recruitment of women was done by newspaper advertisement (Killien et al. 2001), using birth certificates (McGovern et al. 1997), using hospital records (Hyde et al. 1995; Gjerdingen \& Chaloner 1994; Romito et al. 1994; Clark et al. 1997), or using a continental mail panel (Roe et al. 1999). For some papers, study populations were recruited from ongoing studies (Chatterji \& Markowitz 2004; Visness \& Kennedy 1997): (National Maternal and Infant Health Survey NMIHS (Chatterji \& Markowitz 2004; Visness \& Kennedy 1997); Wisconsin Maternity Leave and Health WMLH (Hyde et al. 1995: Clark et al. 1997); Infant Feeding Practices Study IFPS (Roe et al. 1999); Arthur et al. (2003), Killien et al. (2001)). Study populations mostly were not representative of the general female population. In cross-sectional studies, selected women had to be in paid work at the time of the interview. In longitudinal studies, they had to have been in paid work during pregnancy and intending to take up paid work again after childbirth. Paid work was defined - in longitudinal studies - as remunerated work at any time during pregnancy (Killien et al. 2001), or as remunerated work at least $20 \mathrm{~h}$ per week (McGovern et al. 1997). Data collection was performed retrospectively in some studies, ranging from an average of 7 months up to 3 years after delivery in cross-sectional studies. In longitudinal studies, women were followed up to 12 months after childbirth. Two studies did not give the respective information (Arthur et al. 2003; Visness \& Kennedy 1997). With the exception of the ecological studies, the information was based on self-report of included women (by personal interview, or e-mail). A video film was used to evaluate mother-infant interactions in one study (Clark et al. 1997). Health endpoints were assessed by validated questions or scales (CES-D, SOS, PFAS, Spielberger State Anxiety and Anger Inventory, Mental Health Inventory as in the RAND Health Insurance Experiment, PCERA, FPBPA). The information in the ecological studies came from several sources: health indicators mainly from the Organization for Economic Cooperation and Development (OECD); length of maternity leaves from the International Labour Office (ILO).

Length of maternity leave was mostly defined by the number of weeks after childbirth when mothers were off work, with- 
Table 1 Length of maternity leave and maternal health

\begin{tabular}{|c|c|c|c|c|c|}
\hline Author(s) & Study design & $\begin{array}{l}\text { Study population, } \\
\text { year(s) of data } \\
\text { collection, region/ } \\
\text { country }\end{array}$ & Outcome measure & $\begin{array}{l}\text { Exposure: } \\
\text { Length of } \\
\text { maternity leave }\end{array}$ & Results \\
\hline \multicolumn{6}{|l|}{ Maternal health } \\
\hline \multirow[t]{3}{*}{$\begin{array}{l}\text { Chatterji \& } \\
\text { Markowitz } 2004\end{array}$} & \multirow[t]{3}{*}{ cross-sectional } & \multirow[t]{3}{*}{$\begin{array}{l}1762 \text { women. Mothers } \\
\text { of children with } \\
\text { increased postpartum } \\
\text { risk oversampled. } \\
\text { 1988, USA }\end{array}$} & \multirow{3}{*}{$\begin{array}{l}\text { Symptoms of depression } \\
\left(C E S-D^{a}\right) \text { in past week, } \\
\text { on average } 13 \text { months } \\
\text { after childbirth (6-24 } \\
\text { months) } \\
>3 \text { outpatient physician } \\
\text { or clinic visits in first six } \\
\text { months after childbirth }\end{array}$} & \multirow[t]{3}{*}{$\begin{array}{l}<6 \text { versus } 6-8 \\
\text { weeks } \\
<6 \text { versus } 8-12 \\
\text { weeks } \\
<6 \text { versus }>12 \\
\text { weeks }\end{array}$} & $\begin{array}{l}\text { Increasing maternity leave from } \\
6 \text { or fewer weeks to } 8-12 \text { weeks } \\
\text { or }>12 \text { weeks is associated } \\
\text { with a decline in depressive } \\
\text { symptoms of } 11 \% \text { and } 15 \% \text {, } \\
\text { respectively. }\end{array}$ \\
\hline & & & & & $\begin{array}{l}\text { No decline of depressive } \\
\text { symptoms in women with } \\
\text { maternity leave of } 6-8 \text { weeks } \\
\text { in comparison to }<6 \text { weeks, and } \\
\text { in women who are clinically } \\
\text { depressed (CES-D Score }>16 \text { ) }\end{array}$ \\
\hline & & & & & $\begin{array}{l}\text { No association with the number } \\
\text { of outpatient physician or clinic } \\
\text { visits. }\end{array}$ \\
\hline \multirow[t]{2}{*}{ Killien et al. 2001} & \multirow[t]{2}{*}{ longitudinal } & $\begin{array}{l}149 \text { partnered } \\
\text { first-time mothers. } \\
91 \% \text { Caucasian, } \\
\text { predominantly } \\
\text { well educated with } \\
\text { adequate income. }\end{array}$ & \multirow{2}{*}{$\begin{array}{l}\text { Health status (clinical } \\
\text { health/symptom } \\
\text { experience SOS }{ }^{\text {, }} \text {, role } \\
\text { performance PFAS, } \\
\text { global perception } \\
\text { of health) during } \\
\text { pregnancy and } 4,8,12 \\
\text { months after birth }\end{array}$} & \multirow[t]{2}{*}{$\begin{array}{l}\text { Week of return } \\
\text { to employment } \\
\text { after childbirth } \\
\text { (continuous) }\end{array}$} & \multirow[t]{2}{*}{$\begin{array}{l}\text { No association with health } \\
\text { status in the first year after } \\
\text { childbirth }\end{array}$} \\
\hline & & $\begin{array}{l}\text { 1990-1995, USA } \\
\text { (Northwest) }\end{array}$ & & & \\
\hline \multirow[t]{3}{*}{ McGovern et al. 1997} & \multirow[t]{3}{*}{ cross-sectional } & \multirow{2}{*}{$\begin{array}{l}654 \text { women. } 91 \% \\
\text { White, } 67 \% \text { married. } \\
\text { Mothers of children } \\
\text { with increased } \\
\text { postpartum risk } \\
\text { oversampled. }\end{array}$} & $\begin{array}{l}\text { Mental health } \\
\text { (depression, anxiety, } \\
\text { general positive affect; } \\
\text { Stewart) }\end{array}$ & \multirow[t]{3}{*}{$\begin{array}{l}\text { Time off work } \\
\text { after childbirth } \\
\text { in days } \\
\text { (continuous) }\end{array}$} & \multirow{3}{*}{$\begin{array}{l}\text { The association between the } \\
\text { time off work and maternal } \\
\text { health is U-shaped: higher } \\
\text { vitality beyond a length of } 12 \\
\text { weeks, better mental health } \\
\text { beyond } 15 \text { weeks, better role } \\
\text { function beyond } 20 \text { weeks of } \\
\text { leave. }\end{array}$} \\
\hline & & & Vitality (Stewart) & & \\
\hline & & $\begin{array}{l}\text { 1991-1992, USA } \\
\text { (Minnesota) }\end{array}$ & $\begin{array}{l}\text { Role function } \\
\text { (Sherbourne, Stewart, } \\
\text { Ware) in past } 4 \text { weeks, } 7 \\
\text { months after childbirth }\end{array}$ & & \\
\hline \multirow[t]{4}{*}{ Hyde et al. 1995} & \multirow[t]{4}{*}{ longitudinal } & \multirow{2}{*}{$\begin{array}{l}266 \text { women. } 93 \% \\
\text { White. } 53 \% \text { with } \\
\text { college degree or } \\
\text { beyond. }\end{array}$} & Depression (CES-Dª) & \multirow{4}{*}{$\begin{array}{l}6 \text { versus } 12 \\
\text { weeks }\end{array}$} & \multirow{3}{*}{$\begin{array}{l}\text { Maternity leave of } 6 \text { weeks } \\
\text { in comparison to } 12 \text { weeks } \\
\text { is associated with elevated } \\
\text { depression scores in women } \\
\text { with marital concerns and } \\
\text { elevated depression scores and } \\
\text { greater anger in women with } \\
\text { low work rewards ( } 4 \text { months } \\
\text { after childbirth). }\end{array}$} \\
\hline & & & $\begin{array}{l}\text { Anxiety (Spielberger } \\
\text { State Anxiety Inventory) }\end{array}$ & & \\
\hline & & $\begin{array}{l}\text { 1990-1991, USA (Wis- } \\
\text { consin) }\end{array}$ & \multirow[t]{2}{*}{$\begin{array}{l}\text { Anger (Spielberger State } \\
\text { Anger Inventory) in past } \\
\text { week, during pregnancy } \\
\text { and } 1,4 \text { months after } \\
\text { childbirth }\end{array}$} & & \\
\hline & & & & & No association with anxiety. \\
\hline \multirow[t]{3}{*}{$\begin{array}{l}\text { Gjerdingen \& } \\
\text { Chaloner } 1994\end{array}$} & \multirow[t]{3}{*}{ longitudinal } & $\begin{array}{l}436 \text { married, first-time } \\
\text { mothers. }\end{array}$ & \multirow{3}{*}{$\begin{array}{l}\text { Mental health } \\
\text { (depression, general } \\
\text { positive affect, anxiety, } \\
\text { life satisfaction; Mental } \\
\text { Health Inventory used } \\
\text { in the RAND Health } \\
\text { Insurance Experiment) 1, } \\
3,6,9,12 \text { months after } \\
\text { childbirth }\end{array}$} & $\begin{array}{l}<9 \text { versus } 9-24 \\
\text { weeks }\end{array}$ & \multirow{2}{*}{$\begin{array}{l}\text { Better mental health } 9 \text { and } \\
12 \text { months after childbirth in } \\
\text { women with a maternity leave } \\
\text { of }>24 \text { weeks in comparison to } \\
\text { women with }<9 \text { weeks of leave. }\end{array}$} \\
\hline & & \multirow[t]{2}{*}{ 1989, USA (Minnesota) } & & $\begin{array}{l}<9 \text { versus }>24 \\
\text { weeks }\end{array}$ & \\
\hline & & & & & $\begin{array}{l}\text { No significant association with } \\
\text { mental health at } 1,3 \text { and } 6 \\
\text { months after childbirth. }\end{array}$ \\
\hline \multirow[t]{4}{*}{ Romito et al. 1994} & \multirow[t]{4}{*}{ cross-sectional } & \multirow{3}{*}{$\begin{array}{l}141 \text { first-time mothers. } \\
38 \% \text { with only } \\
\text { compulsory education. } \\
88 \% \text { married. }\end{array}$} & Backache & $<12$ versus $13-34$ & \multirow{4}{*}{$\begin{array}{l}\text { No association with backache, } \\
\text { extreme tiredness and lack of } \\
\text { sleep. }\end{array}$} \\
\hline & & & Extreme tiredness & weeks & \\
\hline & & & \multirow{2}{*}{$\begin{array}{l}\text { Lack of sleep } 15 \text { months } \\
\text { after childbirth }\end{array}$} & \multirow[t]{2}{*}{$\begin{array}{l}<12 \text { versus } 35-60 \\
\text { weeks }\end{array}$} & \\
\hline & & $\begin{array}{l}\text { 1988-1989, Italy } \\
\text { (Trieste) }\end{array}$ & & & \\
\hline
\end{tabular}

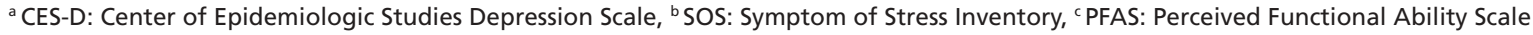


out distinguishing whether it was a paid or unpaid leave, whether it was the legally prescribed length, or whether there was a prolongation of maternity leave. Only Ruhm (2000) separated paid and unpaid leave in the analysis. Maternity leaves in the analytical studies lasted on average 8 to 12 weeks. The age of included women ranged from 28 to 31 , except for one study, where it was 40 years (Arthur et al. 2003).

\section{Results}

\section{Length of maternity leave and maternal health}

Table 1 compiles methods and results of 6 studies that investigated the association of maternity leave with maternal health. Several studies show a positive association between the length of maternity leave and mental health: fewer depressive symptoms were observed in mothers entitled to 8 and 12 weeks leave after childbirth, than in women entitled to less than 6 weeks ((Chatterji \& Markowitz 2004; Hyde at al. 1995) association seen only in women with low work rewards or with marital concerns). Among women with low work rewards, lower levels of anger were observed if maternity leave lasted 12 weeks in comparison to a length of less than 6 weeks (Hyde et al. 1995). General mental health (depression, anxiety, general positive affect, life satisfaction) at 7 and 9-12 months after childbirth was improved in women with maternity leaves beyond 15 weeks and 24 weeks respectively, when compared to leaves of below 9 weeks (McGovern et al. 1997; Gjerdingen \& Chaloner 1994). A positive association with vitality and role function was seen for maternity leaves beyond 12 and 20 weeks, respectively (McGovern et al. 1997).

No association was found between the length of maternity leave and the level of depressive symptoms and mental health respectively, when comparing women with maternity leaves of 6 versus 6-8 weeks (Chatterji \& Markowitz 2004), and when comparing women with leaves below 9 versus 9-24 weeks (Gjerdingen \& Chaloner 1994). Furthermore there was no association in women, who were clinically depressed ((CES-D >16) (Chatterji \& Markowitz 2004)) and no association with anxiety (Hyde et al. 1995). Associations were not observed for further health indicators, such as the number of outpatient physician or clinic visits in the first six months after childbirth (Chatterji \& Markowitz 2004). Nor were associations observed for a summary indicator of health status in the first postpartum year (including clinical health/symptom experience, role performance, global perception of health (Killien et al. 2001), or extreme tiredness, backache and lack of sleep (Romito et al. 1994).

\section{Length of maternity leave and child health}

Two ecological studies investigating the association of the length of maternity leave and child health show consistent results (Ruhm 2000; Winegarden \& Bracy 1995) (Tab. 2).

A slight reduction of perinatal and neonatal mortality was seen with maternity leaves of up to 25 weeks (Ruhm 2000). Longer maternity leaves were associated with a marked decrease of post-neonatal mortality and of child mortality (deaths between 1 and 5 years of age). These two indicators, as well as infant mortality, were reduced by 3 to $4 \%$ per increase of maternity leaves of 10 weeks. In the study of Winegarden et al. (1995), a prolongation of maternity leave of $10 \%$ was associated with a decrease in infant mortality of 3 to $5 \%$. No association was found with low birth weight. Unpaid leave showed no significant association with infant mortality, and there were no further benefits seen with maternity leaves longer than 40 weeks (Ruhm 2000).

\section{Length of maternity leave and quality of mother-infant interactions}

One study has investigated the association of the length of maternity leave and the quality of mother-infant interactions (Clark et al. 1997) (Tab. 2). Four months after childbirth, mothers entitled to short maternity leaves (6 weeks) showed significantly more negative interactions with their infant than women with longer maternity leaves (12 weeks). In addition, women with more physical health symptoms, elevated levels of depressive symptoms, or having a child with difficult temperament, interacted significantly less positively with their child if they were entitled to only 6 weeks of maternity leave than comparable women entitled to 12 weeks of leave. The associations between the length of maternity leave and two scales of child behaviour (negative and positive) were not significant.

\section{Length of maternity leave and breastfeeding}

Table 3 compiles the four studies investigating the association of the length of maternity leave with breastfeeding (duration of breastfeeding and weaning).

Consistently, the duration of breastfeeding was significantly higher in women with longer maternity leaves. According to the studies of Arthur et al. (2003), for the first- and secondborn child, of Yilmaz et al. (2002) for maternity leaves longer than 16 weeks in comparison to shorter leaves, and of Roe et al. (1999), each week of maternity leave increased breastfeeding by almost half a week. Weaning within four months after childbirth is significantly more frequent in women with maternity leaves of less than 8 weeks than in women with longer leaves (Yilmaz et al. 2002). 
Table 2 Length of maternity leave and child health

\begin{tabular}{|c|c|c|c|c|c|}
\hline Author(s) & Study design & $\begin{array}{l}\text { Study population, } \\
\text { region/country }\end{array}$ & Outcome measure & $\begin{array}{l}\text { Exposure: Length } \\
\text { of maternity leave }\end{array}$ & Results \\
\hline \multicolumn{6}{|l|}{ Child health } \\
\hline Ruhm 2000 & ecological & $\begin{array}{l}\text { 1969-1994, } \\
16 \text { European } \\
\text { countries }\end{array}$ & $\begin{array}{l}\text { Infant, perinatal, } \\
\text { neonatal and post- } \\
\text { neonatal mortality }^{\text {a }} \\
\text { Child mortality }^{{ }^{b}} \\
\text { Low birth weight }^{c}\end{array}$ & $\begin{array}{l}\text { Weeks of job-pro- } \\
\text { tected paid paren- } \\
\text { tal leave (continu- } \\
\text { ous) }\end{array}$ & $\begin{array}{l}\text { A } 10 \text {-week extension in paid leave is associated } \\
\text { with a reduction of infant mortality rates by } \\
2.5 \text { to } 3.4 \% \text {, with a decrease of post-neonatal } \\
\text { mortality by } 3.7 \text { to } 4.5 \% \text { and child mortality by } \\
3.3 \text { to } 3.5 \% \text {. } \\
\text { Compared to no leave mandate, } 50 \text {-week enti- } \\
\text { tlement is predicted to reduce infant mortality } \\
\text { by around } 12 \% \text {, post-neonatal mortality by } \\
\text { around } 20 \% \text { and child mortality by around } 20 \% \text {. } \\
\text { Modest but statistically significant reduction in } \\
\text { perinatal and neonatal mortality up to } 25 \text { weeks } \\
\text { of leave. Sharp decrease of post-neonatal and } \\
\text { child mortality with extended entitlements be- } \\
\text { yond } 25 \text { weeks of leave. No further health ben- } \\
\text { efit between } 40 \text { and } 50 \text { weeks of leave. } \\
\text { Leave has no significant effect on birth weight. } \\
\text { Unpaid leave is unrelated to infant mortality. } \\
\text { A substantial leave entitlement might increase } \\
\text { breastfeeding sufficiently to prevent } 0.5 \text { to } 1.0 \\
\text { post-neonatal deaths per } 1000 \text { live births. }\end{array}$ \\
\hline $\begin{array}{l}\text { Winegarden \& } \\
\text { Bracy } 1995\end{array}$ & ecological & $\begin{array}{l}\text { 1959, 1969, } \\
\text { 1979, 1989. } 17 \\
\text { OECD countries } \\
\text { (Europe, USA, } \\
\text { Canada, Japan, } \\
\text { New Zealand) }\end{array}$ & Infant mortality ${ }^{a}$ & $\begin{array}{l}\text { Weeks of paid } \\
\text { maternity leave } \\
\text { (continuous) }\end{array}$ & $\begin{array}{l}\text { An added week of paid maternity leave is } \\
\text { associated with a decrease in infant mortality } \\
\text { of } 0.5 \text { per } 1000 \text { live births; a leave extension of } \\
10 \% \text { with a reduction of infant mortality of } 3 \\
\text { to } 5 \% \text {. }\end{array}$ \\
\hline \multicolumn{6}{|c|}{ mother-infant interactions } \\
\hline $\begin{array}{l}\text { Clark et al. } \\
1997\end{array}$ & longitudinal & $\begin{array}{l}198 \text { women. } \\
92 \% \text { Caucasian. } \\
53 \% \text { with } \\
\text { college degree or } \\
\text { beyond. } \\
\text { USA (Wisconsin) }\end{array}$ & $\begin{array}{l}\text { Quality of mother- } \\
\text { infant interactions, } \\
\text { using four scales } \\
\text { from the PCERA } \\
\text { (Parent-Child } \\
\text { Early Relational } \\
\text { Assessment), } 4 \\
\text { months after } \\
\text { childbirth }\end{array}$ & 6 versus 12 weeks & $\begin{array}{l}\text { Mothers with shorter maternity leaves ( } 6 \text { weeks) } \\
\text { had significantly more Maternal Negative Affect } \\
\text { and Behaviour in interactions with their infants } \\
\text { than mothers with longer leaves ( } 12 \text { weeks). } \\
\text { Women with higher levels of physical health } \\
\text { symptoms, elevated levels of depressive } \\
\text { symptoms or infants having a difficult } \\
\text { temperament, who returned to work earlier (6 } \\
\text { weeks), exhibited less Maternal Positive Affective } \\
\text { Involvement, Sensitivity and Responsiveness in } \\
\text { interactions with their infants than those who } \\
\text { remained on leave longer ( } 12 \text { weeks). } \\
\text { The two infant PCERA Scales showed no } \\
\text { significant association with the length of } \\
\text { maternity leave. }\end{array}$ \\
\hline
\end{tabular}

a Infant mortality: infant deaths under 1 year; perinatal mortality: stillbirths and deaths within 1 week of birth per 1000 live and still births; neonatal mortality: infant deaths under 28 days; post-neonatal mortality: deaths between 28 days and 1 year

${ }^{b}$ Child mortality: deaths between 1 and 5 years of age

' Low birth weight: new-borns weighing less than $2500 \mathrm{~g}$ as $\%$ of live and still births over $1000 \mathrm{~g}$

\section{Assessment for Switzerland}

In Switzerland, the new regulation which came into effect on 1 July 2005 foresees paid maternity leave of 14 weeks, guaranteeing $80 \%$ of the previous wage for all employed women (Bundesamt für Sozialversicherung 2004). The situation as it was before the introduction of the new regulation can only be drawn relying on rough estimations, since there are no national statistics on maternity leaves. According to the Federal Office of Social Security, the Swiss Code of Obligations
("Obligationenrecht") previously constituted the legal basis for the entitlement to continued payment of wages in case of maternity for around $45 \%$ of women in paid work. The Code foresees a minimal entitlement, grading the continued payments according to the years of service in paid work at the same employer, not distinguishing them from payments made because of health problems or accidents (Bundesamt für Sozialversicherung 2004). Also, in the past even around $13 \%$ of women who enjoyed better entitlements, such as those ensu- 
Table 3 Length of maternity leave and breastfeeding

\begin{tabular}{|c|c|c|c|c|c|}
\hline Author(s) & Study design & $\begin{array}{l}\text { Study population, } \\
\text { region/country }\end{array}$ & Outcome measure & $\begin{array}{l}\text { Exposure: length } \\
\text { of maternity leave }\end{array}$ & Results \\
\hline \multicolumn{6}{|l|}{ Breastfeeding } \\
\hline Arthur et al. 2003 & cross-sectional & $\begin{array}{l}146 \text { physician } \\
\text { mothers. } \\
\text { 2000, USA } \\
\text { (Mississippi) }\end{array}$ & $\begin{array}{l}\text { Duration of } \\
\text { breastfeeding } \\
\left.\text { (FPBPA }^{a}\right)\end{array}$ & $\begin{array}{l}\text { Length of } \\
\text { leave in weeks } \\
\text { (continuous) }\end{array}$ & $\begin{array}{l}\text { Positive association between the length of } \\
\text { maternity leave and breastfeeding for first- } \\
\text { and second-born children. }\end{array}$ \\
\hline Yilmaz et al. 2002 & cross-sectional & $\begin{array}{l}301 \text { women, } 53 \% \\
\text { with university } \\
\text { degree. } \\
\text { 1998-1999, Turkey } \\
\text { (Ankara) }\end{array}$ & $\begin{array}{l}\text { Duration of } \\
\text { breastfeeding } \\
\text { Weaning }\end{array}$ & $\begin{array}{l}<8 \text { versus } 9-16 \\
\text { weeks } \\
<8 \text { versus }>16 \\
\text { weeks }\end{array}$ & $\begin{array}{l}\text { Mothers with a maternity leave of more } \\
\text { than } 16 \text { weeks breastfed significantly longer } \\
\text { than women with }<8 \text { and } 9-16 \text { weeks of } \\
\text { leave. } \\
\text { No significant difference in duration of } \\
\text { breastfeeding for leaves of }<8 \text { versus } 9-16 \\
\text { weeks. } \\
\text { Women with a maternity leave of less } \\
\text { than } 8 \text { weeks weaned significantly more } \\
\text { often within } 4 \text { months after childbirth } \\
\text { than women with longer leaves }(9-16,>16 \\
\text { weeks). }\end{array}$ \\
\hline Roe et al. 1999 & cross-sectional & $\begin{array}{l}712 \text { women. White } \\
\text { mothers, women } \\
\text { with higher educa- } \\
\text { tion and larger } \\
\text { household income } \\
\text { oversampled. } \\
\text { 1993, USA }\end{array}$ & $\begin{array}{l}\text { Duration of } \\
\text { breastfeeding }\end{array}$ & $\begin{array}{l}\text { Length of } \\
\text { leave in weeks } \\
\text { (continuous) }\end{array}$ & $\begin{array}{l}\text { Length of work leave contributes } \\
\text { significantly to the duration of } \\
\text { breastfeeding in the first } 12 \text { months after } \\
\text { childbirth. } \\
\text { Largest effect of work leave on } \\
\text { breastfeeding occurs in the first } 12 \text { weeks } \\
\text { after childbirth. } \\
\text { Each week of work leave increases duration } \\
\text { of breastfeeding by almost one half of a } \\
\text { week. }\end{array}$ \\
\hline $\begin{array}{l}\text { Visness \& Kennedy } \\
1997\end{array}$ & cross-sectional & $\begin{array}{l}1506 \text { women. } \\
1988, \text { USA }\end{array}$ & $\begin{array}{l}\text { Duration of } \\
\text { breastfeeding }\end{array}$ & $\begin{array}{l}\text { Length of } \\
\text { leave in weeks } \\
\text { (continuous) }\end{array}$ & $\begin{array}{l}\text { Positive association between the length } \\
\text { of maternity leave and the breastfeeding } \\
\text { duration. }\end{array}$ \\
\hline
\end{tabular}

a FPBPA: Female Physicians' Breastfeeding Practice Assessment

red by a collective bargaining agreement ("Gesamtarbeitsvertrag"), obtained less than 14 weeks paid leave. This was often the case in the health sector, in the sales trade and in industrial branches (Fankhauser 2002). In addition to ensuring a period of 14 weeks, the new law also extends the group of women entitled to continued maternity payment to self-employed women and to women working in family firms. This leads to a substantial improvement for a considerable number of women in case of maternity, compared to the time before 2005 .

Can we expect health benefits for women and children in Switzerland? When applying results of the reviewed studies to Switzerland, without making any restrictions, an extension of maternity leaves from a few to 14 weeks would lead to: a decrease of depressive symptoms; an improvement of maternal vitality; an improvement of the quality of mother-infant interactions; and to a prolongation of breastfeeding. Only an extension beyond 14 weeks would have a positive impact on general mental health (i.e. depression, anxiety, positive affect, life satisfaction), on role performance, and on child health endpoints.

\section{Discussion}

\section{General issues}

Evidence from this review shows that longer maternity leaves are associated with: fewer depressive symptoms; improved mental health; higher vitality; and better role performance in mothers. They are also associated with: a higher quality of mother-infant interactions; and a longer duration of breastfeeding. As to child health, extended maternity leaves are associated with lower mortality up to the fifth year of life.

With these 13 studies, there is rather little empirical research on the association of length of maternity leave and maternal and child health. The only outcome investigated in several studies was maternal mental health (depression, general mental health). We cannot exclude however to have missed some studies with our search strategy.

Health benefits varied for different health endpoints and depending on the length of maternity leave. Even for short leaves (8-12 weeks), a decrease in maternal depressive symptoms, an improvement in the quality of mother-infant 
interactions, better vitality, as well as longer breastfeeding durations were documented in comparison to a reference group with 6-9 weeks of maternity leave. For intermediate lengths of leave (12-25 weeks), improvements were seen for the duration of breastfeeding, for general mental health (depression, anxiety, positive affect, life satisfaction), for maternal role performance, as well as a decrease in perinatal and neonatal mortality, while longer maternity leaves (exceeding 25 weeks) were associated with a decrease of post-neonatal and child mortality. No associations were observed for other indicators, such as the number of outpatient physician or clinic visits within the first six months postpartum, a summary health indicator in the first postpartum year, backache, lack of sleep, and anxiety.

Studies are heterogeneous and there are limitations due to methodological issues. Six of the included studies are crosssectional. Two studies are ecological, although an attempt was made to increase their validity by adjusting for country- and time-specific effects. Possible biases are related to the collection of information (self-report, partially retrospective) and the recruitment of participants. Study populations were mostly not representative of the female population, or only women who returned to work after maternity leave were included. Further methodological problems relate to insufficient control for confounding by maternal education or by health status. Some of the information is not very current, being collected in the late 1980s or early 1990s.

For some health endpoints which were studied twice or several times - as for infant mortality or depressive symptoms, general mental health (depression, anxiety, positive affect, life satisfaction) and duration of breastfeeding - results are however consistent. Longer maternity leaves are consistently associated with fewer mental problems or symptoms and with longer duration of breastfeeding. There are, nevertheless, differences with regard to the time period when a health benefit becomes evident, and with regard to conditions relevant for seeing an impact. When compared with results of cross-sectional studies, longitudinal studies on maternal mental health showed benefits for comparatively longer maternity leaves, or only where additional risk factors (such as low work rewards or marital concerns) were at play.

Less evidence is available for other health endpoints such as vitality, role performance, number of maternal outpatient physician/clinic visits, quality of mother-infant interactions, infant/ child mortality rates, studied only once. Caution is also advised regarding conclusions pertaining to causal relationships in the ecological studies on infant mortality. However, health benefits of longer maternity leaves for children are plausible against the background of the established association of breastfeeding with better child health (Yngve \& Sjöström 2001).

\section{Assessment of the situation in Switzerland}

Most reviewed studies were conducted in the USA, a country with major differences to Switzerland in the social security system and health care. Not all women in the USA are entitled to (paid or unpaid) maternity leave (Kamerman 2000). Mean length of maternity leaves in the studies was 8-12 weeks, and in some studies, the educational level of included women is higher compared to women of the overall population. Comparatively, women in Switzerland with maternity leaves of 8-12 weeks tend to have rather lower levels of education and to belong to lower socio-economic groups (Staehelin et al. 2004; Fankhauser 2002). Therefore, study results cannot be transferred without caution to Swiss women entitled to these lengths of maternity leave. Furthermore, most studies did not assess the length of maternity leave to which women would have been entitled by law; instead they assessed the number of postpartum weeks when women were not in paid work. The length of maternity leaves in Switzerland may actually be higher than the legally prescribed 14 weeks, since some employers provide more than these 14 weeks and since after this period, additional unpaid leaves can be obtained. Therefore, the results of studies with intermediate length of leave (12-25 weeks) may be appropriate to Switzerland. Regrettably, with one exception (Romito et al. 1994), no European studies were found, providing better comparability with Switzerland. Even for northern Europe with its more developed parental leave policies, there is only one case study focussing on labour market policy and breastfeeding in Ireland, Sweden and the USA (Galtry 2003). This study does not, however, present associations of length of maternity leave and breastfeeding duration.

Against this background, the new policy installed on 1 July 2005 , entitling all women in remunerated employment in Switzerland to 14 weeks of paid maternity leave, may lead to an improvement of maternal mental health and to an extension of breastfeeding duration, in particular in women who previously were entitled to a minimal leave and/or who present with additional social risk factors.

\section{Conclusions}

Overall, results show that longer maternity leaves are associated with improvements in maternal mental health and with longer breastfeeding durations. For child health outcomes extended maternity leaves were associated with lower perinatal, neonatal and post-neonatal mortality rates as well as child mortality; however, these results are obtained in ecological studies. With regard to all other endpoints of maternal 
and child health, the results are less conclusive due to scarce data or methodological problems and more research is needed to clarify the associations with the length of maternity leave. However, legal regulations increasing maternity leaves from a few weeks to 8-12 weeks or more are likely to lead to health benefits. This is expected to be the case also in Switzerland, where the new policy leads to longer maternity leaves for a large proportion of women in the labour force.

\section{Acknowledgements}

The literature search in this publication was funded by the Swiss Federal Office of Public Health.

\begin{abstract}
References
Arthur CR, Saenz RB, Replogle WH (2003). The Employment-Related Breastfeeding Decisions of Physician Mothers. J Miss State Med Assoc 44(12): 383-7.
\end{abstract}

Bundesamt für Sozialversicherung (2004). Faktenblatt EO-Revision. Bern, Juli 2004. http: //www.bsv.admin.ch/eo/aktuell/d/d_Faktenblaetter_040802.pdf

Bundesamt für Statistik (eds.) (2004). Statistisches Jahrbuch der Schweiz. Zürich: Verlag Neue Zürcher Zeitung.

Chatterji P, Markowitz S (2004). Does the Length of Maternity Leave affect Maternal Health? Natl Bur Econ Res, Working Paper 10206, Cambridge, January.

Clark R, Hyde JS, Essex MJ, Klein MH (1997). Length of Maternity Leave and Quality of Mother-Infant Interactions. Child Dev 68(2): 364-83.

Fankhauser L (2002). Verankerte Gleichstellung? Eine branchenübergreifende Gleichstellungsanalyse von Gesamtarbeitsverträgen. Eine Studie im Auftrag des Schweizerischen Gewerkschaftsbundes, Dossier 15. Schweizerischer Gewerkschaftsbund, Bern.

Galtry J (2003). The impact on breastfeeding of labour market policy and practice in Ireland, Sweden, and the USA. Soc Sci Med 57(1): 167-77.

Gjerdingen DK, Froberg DG, Kochevar L (1991). Changes in Women's Mental und Physical Health from Pregnancy Through Six Months Postpartum. J Fam Pract 32(2): 161-6.

Gjerdingen DK, Chaloner KM (1994). The Relationship of Women's Postpartum Mental Health to Employment, Childbirth and Social Support. J Fam Pract 38: 465-72.

Hyde JS, Klein MH, Essex MJ, Clark R (1995). Maternity Leave and Women's Mental Health. Psychol Women Q 19: 257-85.

Kamerman SB (2000). From Maternity Leave to Parental Leave Policies: Women's Health, Employment and Child and Family Well-Being. JAMWA 55(2): 96-9.
Killien MG, Habermann B, Jarrett M (2001). Influence of Employment Characteristics on Postpartum Mother's Health. Women Health 33(1-2): 63-81.

Kommission der Europäischen Gemeinschaften (1999). Bericht der Kommission über die Durchführung der Richtlinie 92/85/EWG des Rates vom 19. Oktober 1992 über die Durchführung von Massnahmen zur Verbesserung der Sicherheit und des Gesundheitsschutzes von schwangeren Arbeitnehmerinnen, Wöchnerinnen und stillenden Arbeitnehmerinnen am Arbeitsplatz. Brüssel, 15.3.1999. http: //europa.eu.int/comm/ employment_social/equ_opp/news/preg-de.pdf

Kommission der Europäischen Gemeinschaften (2003). Bericht der Kommission über die Umsetzung der Richtlinie 96/34/EG des Rates vom 3. Juni 1996 zu der von UNICE, CEEP und EGB geschlossenen Rahmenvereinbarung über Elternurlaub. Brüssel, 19.6.2003. http: //europa. eu.int/comm/employment_social/equ_opp/documents/com2003358_de.pdf

McGovern P, Gjerdingen DK, Froberg DG (1992). The Parental Leave Debate: Implications for Policy Relevant Research. Women Health 18(1): 97-118. Review.

McGovern P, Dowd B, Gjerdingen D, Moscovice I, Kochevar L, Lohmann W (1997). Time Off Work and the Postpartum Health of Employed Women. Med Care 35(5): 507-21.

Mutual Information System on Social Protection in the EU Member States and the EEA MISSOC (2004). MISSOC-Tabellen, 05/2004, Mutterschaft/Vaterschaft, Familienleistungen. http: //www.europa.eu.int/comm/employment_social/ missoc/missoc2004_may_de.pdf

Roe B, Whittington LA, Beck Fein S, Teisl MF (1999). Is there Competition between BreastFeeding and Maternal Employment? Demography 36(2): 157-71.

Romito P, Saurel-Cubizolles MJ, Cuttini M (1994). Mother's Health After the Birth of the First Child: The Case of Employed Women in an Italian City. Women \& Health 21(2/3): 1-22.

Ruhm CJ (2000). Parental leave and child health. J Health Econ 19(6): 931-60.
Staehelin K, Coda Bertea P, Zemp Stutz E (2004). Schwangerschaft, Mutterschaft, Erwerbstätigkeit und Gesundheit. Bundesamt für Gesundheit, Bern. http: //www.bag.admin.ch/gender/forschung/forschungsthemen/f/studie.pdf

Visness CM, Kennedy KI (1997). Maternal Employment and Breast-Feeding: Findings from the 1988 National Maternal and Infant Health Survey. Am J Public Health 87(6): 945-50.

Yip PS, Chi I, Chiu H, Chi Wai K, Conwell Y, Caine $E$ (2003). A prevalence study of suicide ideation among older adults in Hong Kong SAR. International Journal of Geriatric Psychiatry 18(11): 1056-62.

Winegarden CR, Bracy PM (1995). Demographic Consequences of Maternal-Leave Programs in Industrial Countries: Evidence from Fixed-Effects Models. South Econ J 61(4): 1020-35.

World Health Organization WHO Regional Office for Europe (2004). HFA Database, June 2004. http: //www.euro.who.int/HFADB

Yilmaz G, Gürakan B, Akgün S, Özbek N (2002). Factors influencing breastfeeding for working mothers. Turk J Pediatr 44(1): 30-4.

Yngve A, Sjöström M (2001). Breastfeeding in countries of the European Union and EFTA: current and proposed recommendations, rationale, prevalence, length and trends. Public Health Nutrition 4(2b): 631-45.

\section{Address for correspondence}

Katharina Staehelin Institute of Social and Preventive Medicine, University of Basel Steinengraben 49

CH-4051 Basel, Switzerland

Tel.: +41 612702213

Fax: +41 612702225

e-mail: katharina.staehelin@unibas.ch

Elisabeth Zemp Stutz

Institute of Social and Preventive Medi-

cine, University of Basel

Steinengraben 49

CH-4051 Basel, Switzerland

Tel.: +41 612702226

Fax: +41 612702225

e-mail: elisabeth.zemp@unibas.ch 